\title{
INTENSITY ANd PERCEPTION OF BARRIERS OF CUSTOMER SATISFACTION MEASUREMENT
}

\author{
Peter Madzík $^{1}$; Pavol Križo ${ }^{2}$ \\ ${ }^{1}$ Catholic university in Ružomberok, Faculty of Education, Department of Management, \\ Nábrežie Jána Pavla II., 15, 05801 Poprad, Slovakia \\ ${ }^{2}$ College of Economics and Management in Public Administration in Bratislava, \\ Furdekova 16, 05104 Bratislava, Slovakia \\ e-mail: ${ }^{1}$ peter.madzik@ku.sk; ${ }^{2}$ pavol.krizo@ vsemvs.sk
}

\begin{abstract}
Although information resulting from measurement of customer satisfaction (CS) belongs to worthy starters of improvement activities in practice of an organization, they face various barriers which prevent measurement to become systematic. The aim of this study is to research intensity and perception of barriers preventing CS measurement. To achieve the goal, statistic processing of the research results which was done in Slovak republic is used. Totally 435 valid questionnaires were processed and relations among individual barriers of CS measurement were identified and quantified. The results showed that occasional measurement of CS and a lack of personnel are considered to be the biggest ones.
\end{abstract}

\section{Keywords}

Customer satisfaction measurement; Barriers; Survey.

\section{Introduction}

Impacted by globalization growth and hyper-competition existence, quality management theories started to concentrate on customer satisfaction more widely at the beginning of the 80's of the 20th century. Customer satisfaction (CS) as a technical term gets gradually into a higher number of industries (marketing, industrial engineering, service management, etc.) and nowadays it belongs to permanent challenges of every organization. There is empirical evidence confirming that CS is a key determinant of organization market success [15]. Positive effects of high CS often become the object of research of several studies in managerial [12], economic [5] or social areas [2]. At present it would be very difficult to disprove the assertion that focusing on CS high level achievement should belong among marginalized areas related to organization effort [12]. A principle of achievement of high CS was integrated to several managerial standardized and open concepts. One of the best known standards which CS presents as one of key strategic goals is ISO 9001: Quality management systems. The standard explicitly and systematically "navigates" an organization through its processes so that also customer requirements aimed at achievement of their high satisfaction are taken into consideration. Also other concepts like EFQM or its modified version CAF present necessity to focus on CS as the most concerned part.

To get to know how CS "is created" it is necessary to introduce a wider context of quality management process. In the past, summary approaches to analyse, integrate, manage, and improve customer requirements fulfillment were determined and one of the most universal one was created in the area of Service science. Its authors Parasuraman, Zeithaml, and Berry [10] suggested a model based on GAP principle - i.e. differences between expectations and 
reality. Later the model was slightly modified getting its universal form and named as quality loop.

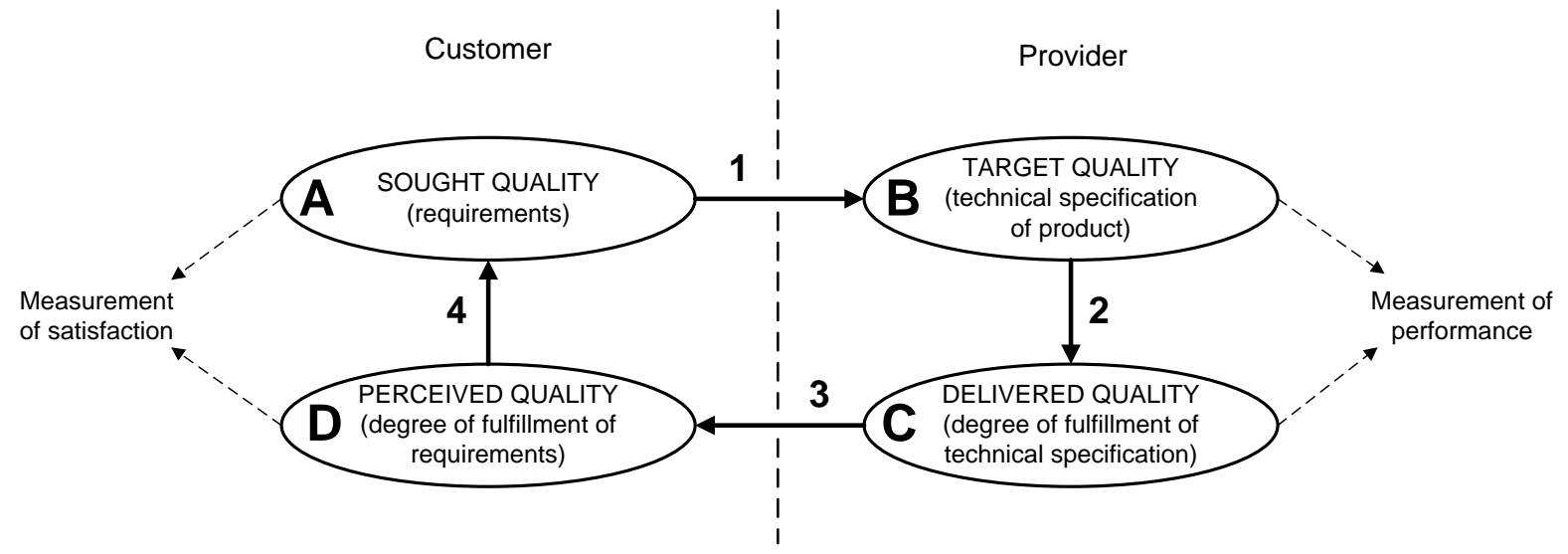

Source: Adapted from [4]

Fig. 1: Quality loop

Quality loop is a graphic representation of quality management process which presents its elements and relations among them (Figure 1). As can be seen there are usually two concerned parties in quality process - a customer and a provider. To achieve acceptable quality degree, at first, an organization has to know customer requirements (part A) and integrate them into product technical specification (B). Designing techniques such as Quality function deployment [6] is most frequently used in case of product quality integration. Consequently, an organization has to ensure the highest possible degree of technical specification fulfillment $(\mathrm{C})$. After the product delivery, customers are confronted with its technical (inherent) and assigned characteristics and perceive the degree of their own requirements fulfillment (D). Determination of conformity rate between expectations (A) and perception (D) is in the quality theory called measurement of customer satisfaction [9].

\section{$1 \quad$ Aims of Research}

In spite of provable benefits of CS measurement, there are still various barriers which prevent the process of CS measurement to become a key process of each organization activities validation. Professional and scientific literature introduces several barriers related especially to economic difficulty of satisfaction measurement process [7], although a deeper analysis which would explain the character and the structure of the barriers with reference to a wider context of organization performance is still missing. The aim of the study is to (1) characterize most frequent barriers of CS measurement, (2) get to know their mutual relations better, (3) identify mutual relations between perceived benefit of CS measurement and perceived importance of CS measurement, (4) explore relations between organization results and emphasis on periodicity and systematic nature of CS measurement and (5) identify and characterize groups of organizations having a similar structure of barriers of CS measurement.

\section{$2 \quad$ Methodology}

To deal with the topic, a standard procedure based on four phases of research was proposed, see Figure 2. During the planning phase professional and scientific sources were reviewed and most frequently mentioned CS measurement barriers were extracted. Apart from the above mentioned barriers the questionnaire contains other variables, e.g. indicators of company perceived success, additional ID attributes or appraisal of opinions related to CS measurement. These additional variables enabled deeper stratification of the results aimed at better understanding of CS measurement barriers structure. After that the questionnaire was 
made and forms of questions and typology of responses was considered to achieve data of the highest analytical potential. Apart from common scaling in the interval 1 to 5 and 0 to 100 , approaches concerning agreement evaluation were used [10], since some of them in specific cases show a more accurate degree of assessment from the point of respondents. When the electronic questionnaire had been processed, a database containing e-mail contacts of organizations operating (performing) in the Slovak Republic was created.

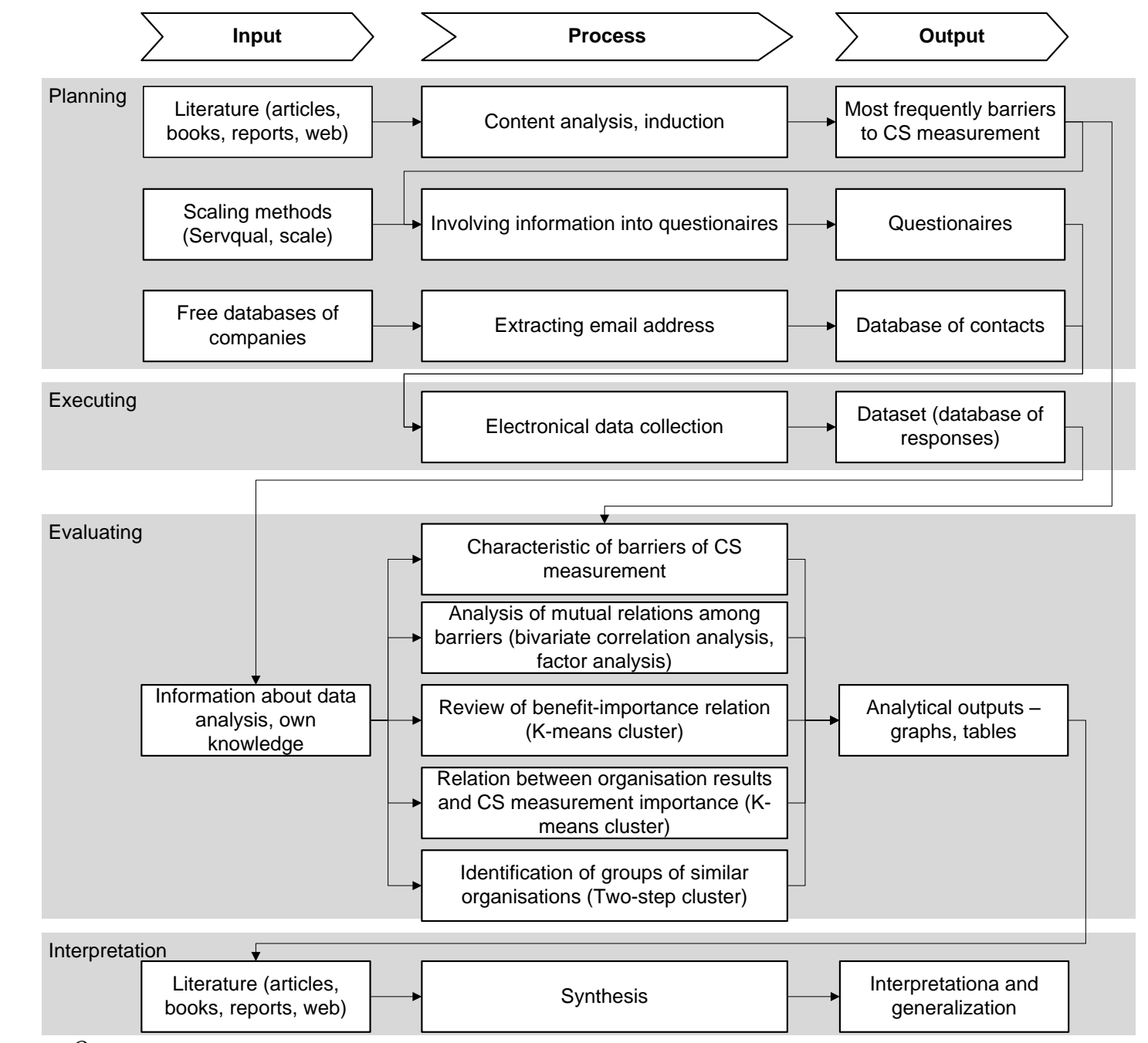

Source: Own

\section{Fig. 2: Research design}

During the realization phase the data were gathered in March and April 2016 and the outputs resulting from the responses - after being checked due to data consistency - were exported to formats enabling execution of common (Excel) and more advanced (IBM SPSS Statistics) statistic procedures. These procedures were executed in the phase of results evaluation and reflected research aims named in the final part of Introduction. Based on the acquired data as well as on information from the planning phase, it was possible to explore 5 main areas systematically. The first one was the characteristic of the main barriers of CS measurement and frequency graphs and stratification according to size and sector of organization. The second area of the research was the analysis of mutual relations among barriers by bivariate correlation analysis and later by factor analysis based on principal component analysis. In the next (the third) area, mutual relation between perception of CS measurement importance and expected benefit which a measurement is to bring was reviewed. To do so, $k$-means cluster analysis was used and it was interpreted by a scatter-dot chart. The objective of the fourth area 
was to confirm validity of CS measurement by analysis of relation between the results an organization achieves and importance which organization attaches to the process of CS measurement. The last fifth area was aimed at summary characteristic of similar organizations considering their size, sector and barriers.

Analytical outputs in a form of charts and tables were explained during the phase of research interpretation and generalized in discussions and related to the existing knowledge in the area of CS measurement or other wider connections.

\section{$3 \quad$ Results and Discussion}

Electronic survey aimed at data collection was realized within the Slovak Republic during March and April 2016. Totally approximately 10,000 organizations doing business in various areas were addressed and the number of valid responses was 435. Organizations from 21 economic activities were represented in the number of valid responses (categories were adapted from SR Statistical Office classification).

\subsection{Main Barriers of CS Measurement}

Gathering and evaluation of quantitative and qualitative data has a critical importance for an organization. The structure of data, parameters, indicators or other numerical, graphical or verbal forms of assessment of the past, current, eventually future situation of an organization is usually named a Measurement System. This system is to support decision making based on facts and help an organization to achieve strategic goals [3]. It is neither possible nor reasonable to measure everything and so it is a natural choice of an organization to define what, why and how should be measured. In Figure 3 simple results showing the rate of systematic CS measurement are displayed.
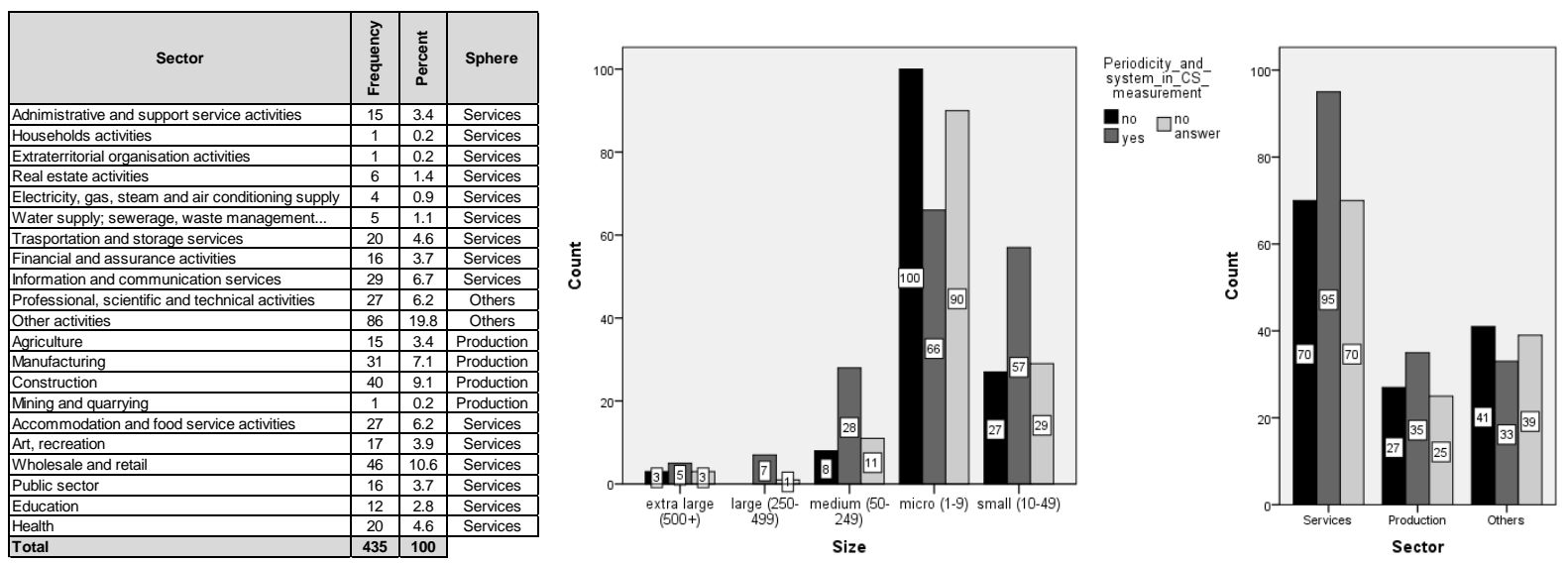

Source: Own calculation

Fig. 3: Periodicity and system in CS measurement from size of organization and sector points of view

As one can see, the absence of the system in CS measurement is obvious especially in micro companies. Influenced by increasing number of organization employees also its approach to CS measurement goes up, and majority of medium and large organizations consider their effort in this area as the systematic one. The results also showed that a difference between production and service sector is - from the point of view of ratio between systematic and nonsystematic CS measurement - insignificant.

In literature several reasons confirming insufficient attention of organizations to process of CS measurement can be found [11] and the most frequently mentioned are the following ones: 
- Needs of our customer are stable - this is an argument used especially by companies offering commodities, or operating in network-regulated industries or in monopolistic environment to state their low interest in CS measurement. In principle, this statement may not be correct since globalization and development trends accelerate tendencies related to increasing requirements of customers [13].

- Lack of personnel - a frequent reason especially in organizations with cumulated functions and a low number of employees [14].

- Finance - reasons that CS measurement is costly belong among most frequently presented ones [14].

- Occasional measurement of CS - reactive attitude of an organization is behind this reason and the organization uses CS measurement only in a situation when a sudden initiator usually has a negative character emerges (e.g. massive complaints, decline in sales, etc.). In this way organizations use CS measurement as a tool to diagnose the cause of a negative situation [8].

- Annoyed customer - organizations are afraid that CS measurement will make customers annoyed and this fact is seen as a barrier to use CS measurement systematically [4].

- We do not need to do periodical measurement of CS - a role in systematic implementation of CS measurement is also played by superior conviction of managers that CS measurement does not have to be regular and should have only supportive character [8]. The main adversaries of quality are a lack of interest and a lack of knowledge - the barrier presenting the former one.

- No benefit - the second adversary of quality is a lack of knowledge. There are several studies pointing out that managers are not often aware of strategic importance of CS measurement [8].

These seven main causes evaluated by organizations which measure CS non-systematically or do not measure it at all became the object of analysis researching the rate of influence of individual barriers of CS measurement. Results in Figure 4 show that the biggest barrier is "Occasional measurement of CS" (average barrier intensity was 62.3 calculated in scale 0 to 100). A finding that organizations are aware of benefits resulting from CS measurement is considered to be positive information and this is proved by relatively low intensity of "No benefit" barrier (average barrier intensity 42.2). An exception is a group of respondents presenting extra-large organizations but since only a very low number of such organizations were involved in the research it is not possible to define any conclusions.
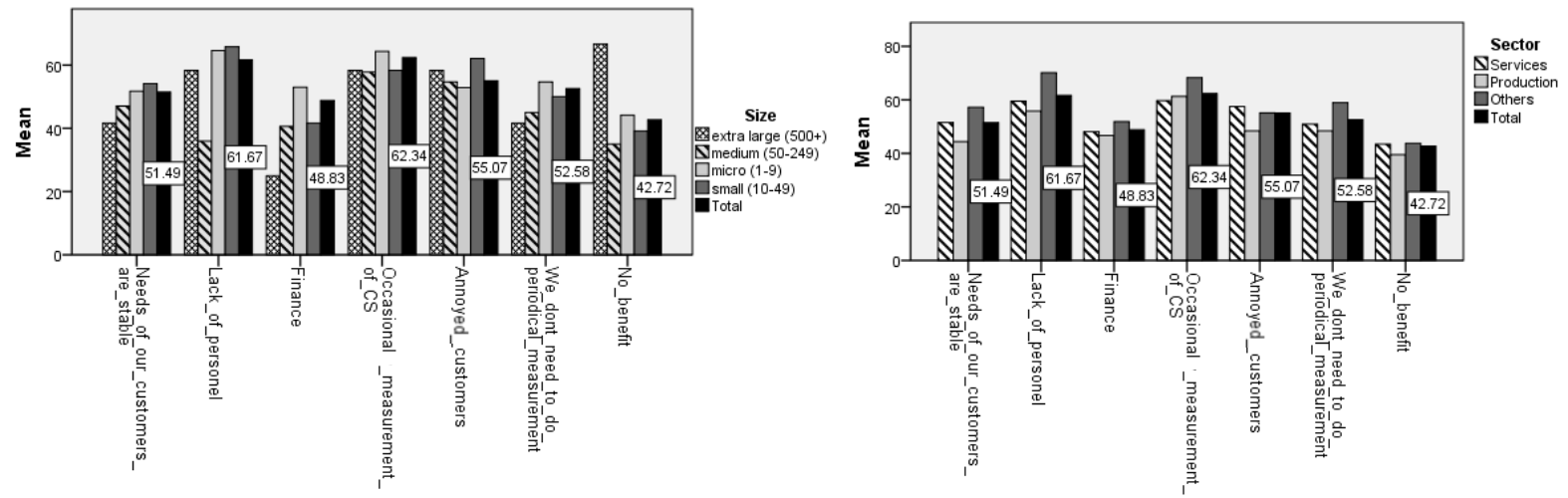

Source: Own calculation

Fig. 4: Intensity of CS measurement barriers; stratification according to size (on the left) and sector (on the right) 
Problems related to insufficient capacity of personnel to measure CS ("Lack of personnel") achieved relatively high level in micro and small organizations. Stratification of the results according to the size brought only relatively consistent results. Stratification of the results according to the sector showed differences between service and production sector. Belief that "needs of our customers are stable" and that CS measurement will make our customers annoyed ("Annoyed customers") is higher in case of service sector. To verify statistical significance of this difference Two-sample $F$-test for variances in combination with $t$-test were used. Statistical procedure based on $F$-test applying stratification of both mentioned barriers resulted to a partial conclusion that variances of both samples are identical and that Two-sample $t$-test assuming equal variances is suitable to verify statistical significance. In both cases it confirmed that values $t_{\text {stat }}$ are lower than $t_{\text {crit }}$ (in the first case $t_{\text {stat }} / t_{\text {crit }}$ results were at the level $-1.20 / 1.98$, in the second one -1.65/1.98) and so it is possible to state that a difference between production and services is not statistically significant.

\subsection{Relations Among Barriers of CS Measurement}

To understand internal structure of barriers in customers' minds better it is appropriate to research their mutual relations (connections, links). For this purpose, approaches based on correlation indexes/coefficients are used most frequently [1]. Best known are correlation and factor analysis. In the first phase relations among individual barriers were examined by bivariate correlation analysis, which presents intensity of mutual dependencies by Pearson correlation coefficient $\mathrm{p}$ moving in the interval $\langle-1 ; 1\rangle$.

There are results of bivariate correlation analysis in Table 1 that do not show strong explicit relations among investigated barriers. Barriers with $p \leq-0.5$ or $p \geq 0.5$ are considered as strong ones. Absence of strong explicit relations may not mean that there are no latent relations presented by latent variables among barriers. To research this option factor analysis is applicable too. That is why a data set was subjected to a factor analysis procedure.

Tab. 1: Results of bivariate correlation analysis

\begin{tabular}{|c|c|c|c|c|c|c|}
\hline Variable & $\begin{array}{c}\text { G No } \\
\text { benefit }\end{array}$ & $\mathbf{F}$ & $\mathbf{E}$ & D & $\mathbf{C}$ & B \\
\hline A Needs of our customers are stable & 0.132 & 0.170 & -0.050 & 0.129 & 0.058 & -0.049 \\
\hline B Lack of personnel & 0.096 & 0.095 & 0.014 & 0.072 & 0.345 & \\
\hline C Finance & 0.277 & 0.149 & 0.161 & 0.138 & & \\
\hline D Occasional measurement of CS & 0.112 & 0.326 & 0.292 & & & \\
\hline E Annoyed customers & 0.291 & 0.317 & & & & \\
\hline $\begin{array}{l}\text { F We don't need to do periodical } \\
\text { measurement }\end{array}$ & 0.462 & & & & & \\
\hline
\end{tabular}

During examining seven barriers the factor analysis procedure identified, three components (latent variables) in which values lower than 0.2 were hidden (for clarity reason) in Figure 5. Considering the intensity of their relations with barriers they were named as (1) Concerns of consequences, (2) Capacity constraints, and (3) Illusion of status quo. These three components explain in total $62.65 \%$ of variables variability. The component "Concerns of consequences" mostly consists of barriers like "Annoyed customers", "We do not need to do periodical measurement", "Occasionally measurement of CS" and "No benefit". It concerns general barriers which result from not knowing benefits and worries of something the effect of which is not seen immediately but after some time. The second identified component was "Capacity constraints" which mostly contains two barriers - "Lack of personnel" and "Finance". It concerns closely connected barriers which, as the previous analysis proved in Chapter 3.1, are 
characteristic especially for micro and small organizations. The last identified component was "Illusion of status quo", i.e. belief that "Needs of our customers are stable". In a large extent this component consisted only of one barrier of the same name. This in principle not totally appropriate attitude of respondents may result from either self-conviction about perfect market knowledge, organization monopolistic position or simply from not being aware of the growing requirements of customers in market environment.

\begin{tabular}{|c|c|c|c|}
\hline \multicolumn{4}{|c|}{ Rotated Component Matrix ${ }^{a}$} \\
\hline & \multicolumn{3}{|c|}{ Component } \\
\hline & $\begin{array}{l}\text { 1: Concerns of } \\
\text { consequences }\end{array}$ & $\begin{array}{l}\text { 2: Capacity } \\
\text { constraints }\end{array}$ & $\begin{array}{l}\text { 3: lllusion of } \\
\text { status quo }\end{array}$ \\
\hline Annoyed_customers & 0.781 & & -0.284 \\
\hline $\begin{array}{l}\text { We_dont_need_to_do_periodical_ } \\
\text { measurement }\end{array}$ & 0.696 & & 0.322 \\
\hline Occasionally_measurement_of_CS & 0.609 & & \\
\hline No_benefit & 0.563 & 0.296 & 0.318 \\
\hline Lack_of_personel & & 0.834 & \\
\hline Finance & 0.223 & 0.769 & \\
\hline $\begin{array}{l}\text { Needs_of_our_customers_are_sta } \\
\text { ble }\end{array}$ & & & 0.917 \\
\hline
\end{tabular}

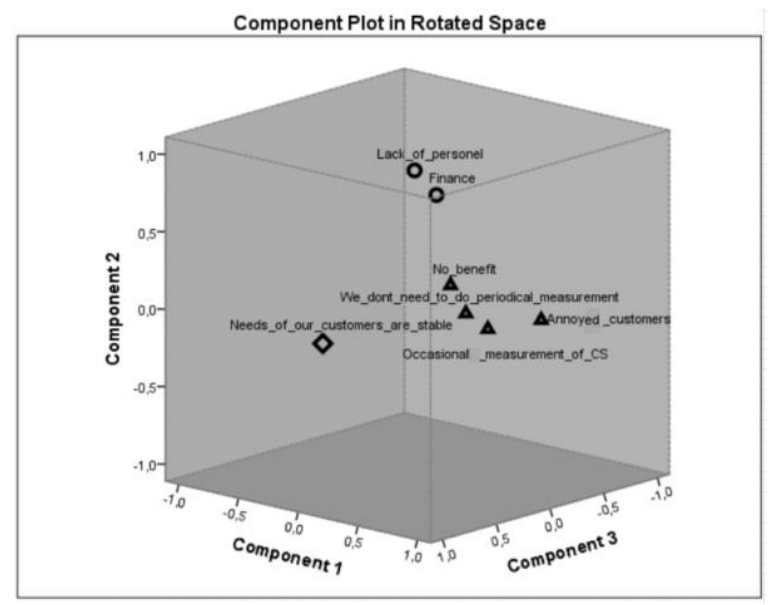

Source: Own calculation

Fig. 5: Identification of latent variables by factor analysis

\subsection{Relation Between Perceived Benefit and Attributed Importance of CS Measurement}

Literature brings a lot of logical and empirical reasons to make organizations pay systematic attention to CS measurement. But how do organizations perceive it? One of the aims of this paper is to clarify it in part. To do so, two individual variables (questions in the questionnaire) were used. The first one was perceived benefit of CS measurement. It may be assumed that organizations will pay more effort to activities bringing demonstrable benefit. The second question was to set the importance of CS measurement. This is not duplicity of the first question since this one helps understand positioning of "measurement of CS" activity in the hierarchy of all organization activities. Respondents could response to both questions in a scale $0-100$ and consequently a scatter-dot graph enabled to display mutual configuration of individual cases, see Figure 6.

Scattering of individual cases in a two-dimension system was used to enable linear regression (in both cases it has growing character). In case of the production sector a regression curve has a steeper inclination that in the service sector. It means that setting the importance of CS measurement is higher in the production sector. It may be assumed that the reason is one particular feature of services, i.e. a direct contact with the customer/target consumer. Since in case of services this contact is more frequent than in case of production, it may be predicted that customers' requirements are recorded immediately in the process of services provision and potential corrections in service characteristic might be done relatively quickly. CS measurement might be perceived only as complement to customers' requirements understanding. But in case of the production the final product is validated after its production has been finished and for an organization CS measurement is a way to identify the degree to which a product meets customers' requirements. 

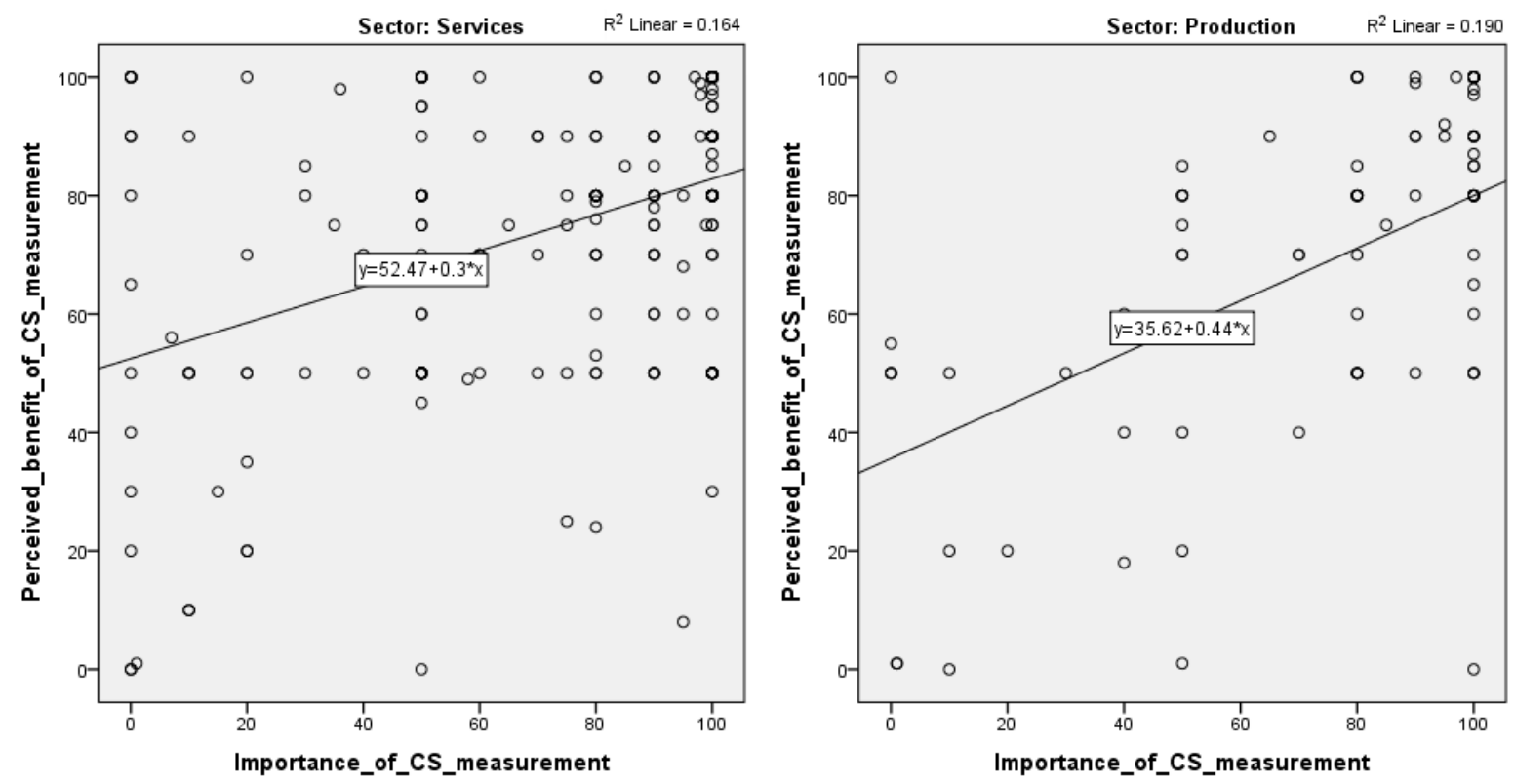

Source: Own calculation

Fig. 6: Relation between perceived benefit and importance of CS measurement; service sector (left), production sector (right)

Several risks are to be mentioned due to the above mentioned statements. They are related to arguments strength. Relatively low value of $R^{2}$ (coefficient of determination) which determines how close the data are to the fitted regression should be considered, and so these interpretations should be taken as possible explanation.

\subsection{Relation Between Organization Results and Emphasis on CS Measurement}

Several positive examples confirmed that organizations which pay systematic attention to CS measurement achieve better market results [8]. The research which was a part of this presented one was a very good opportunity to verify the stated results empirically. Since the electronic way of questioning was anonymous, only subjective indicators of organization results were obtained. To prevent problems concerning results comparison, since organizations have different results indicators across sectors and also different ones due to their size, it was decided to use a scale 0-100 to evaluate their own results. The results were evaluated by two variables: success of organisation and market position of an organisation. Responses were divided into two categories, the first one being presented by organizations which pay systematic attention to CS measurement and the second one including organizations which do not measure CS systematically. The results were processed in a form of scatter-dot chart utilizing the principle of cluster analysis, see Figure 7.

The coordinate system might be divided into four quadrants. There are unsuccessful organizations with a low market position (power, share) at the left bottom. At the right bottom there are several organizations whose market power is very high but are not considered to be successful - they are supposed to operate in monopolistic environment. On the left top there are usually small organizations with a relatively low market position but considered as rather successful. On the right top there are market leaders from both points of view - their market position and perception of their own success. 

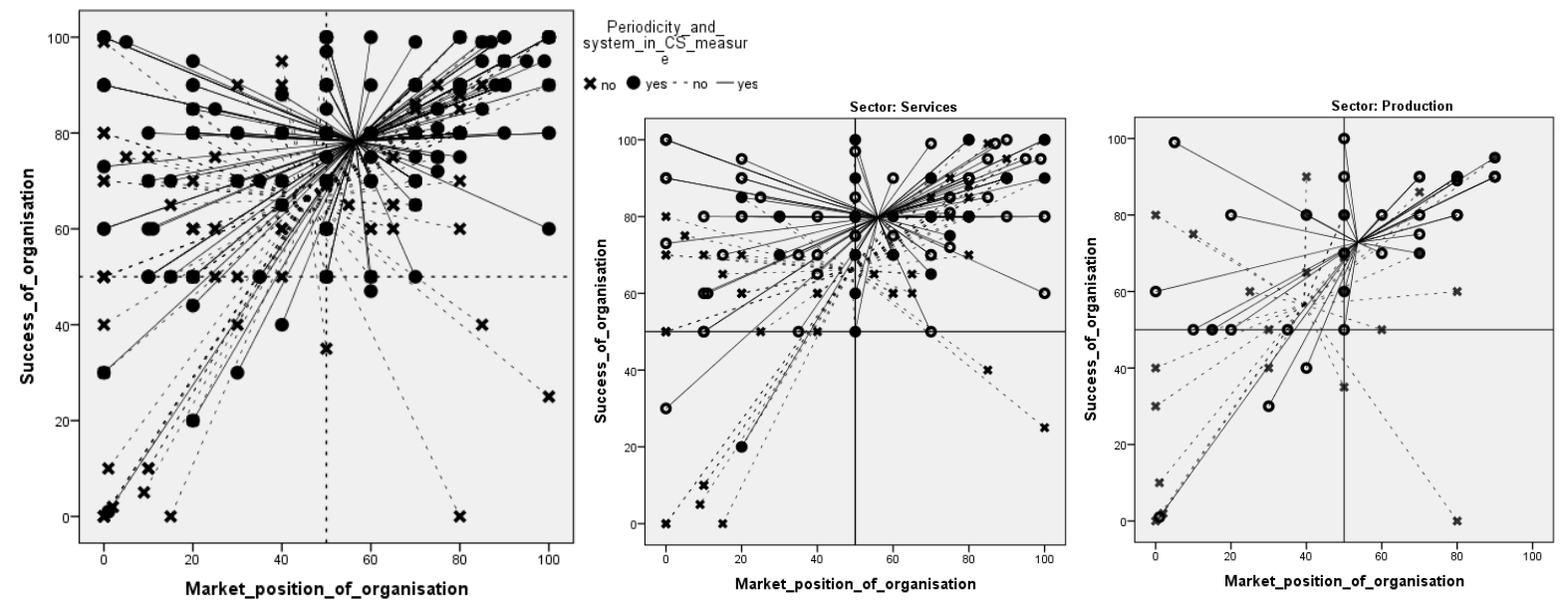

Source: Own calculation

Fig. 7: Achievement of organization results due to periodicity and system in CS measurement; all the organizations (on the left), service sector (in the middle) and production sector (on the right)

Individual organizations are represented in the coordinate system by corresponding points distinguished according to the fact whether an organization (1) pays or (2) does not pay systematic attention to CS measurement. Calculation of centroid of these two groups results to average position of organizations. In the coordinate system $(x ; y)$ the centroid of organizations paying systematic attention to $\mathrm{CS}$ measurement was in the right top quadrant and its coordinates were $(56.6 ; 78.2)$ and the centroid of organizations which do not measure CS systematically was in the left top quadrant and its coordinates were (45.6; 66.3). Based on this, it may be stated that CS measurement has an impact on organization results particularly on their success (in higher extent) and later also on their market position (in lower extent). Similar conclusions may be induced from data stratification for the service as well as for the production sector, see Figure 7 in the middle and on the right.

\subsection{Groups of Similar Organizations}

The survey which had been performed enabled execution of further statistical procedures clarifying uncertainties concerning causes barriers of CS measurement. Relatively valuable information is the identification of type representatives, i.e. groups of comparatively homogeneous subjects whereby these groups are mutually heterogeneous. For this purpose, it is best to use cluster analysis and in this paper two-step cluster analysis was applied. Five variables entered the procedure of clustering: the size of the organization, sector, concerns of consequences, capacity constraints and illusion of status quo. Last three variables presented an output from factor analysis introduced in Chapter 3.2. The results of this clustering are displayed in Figure 8. 

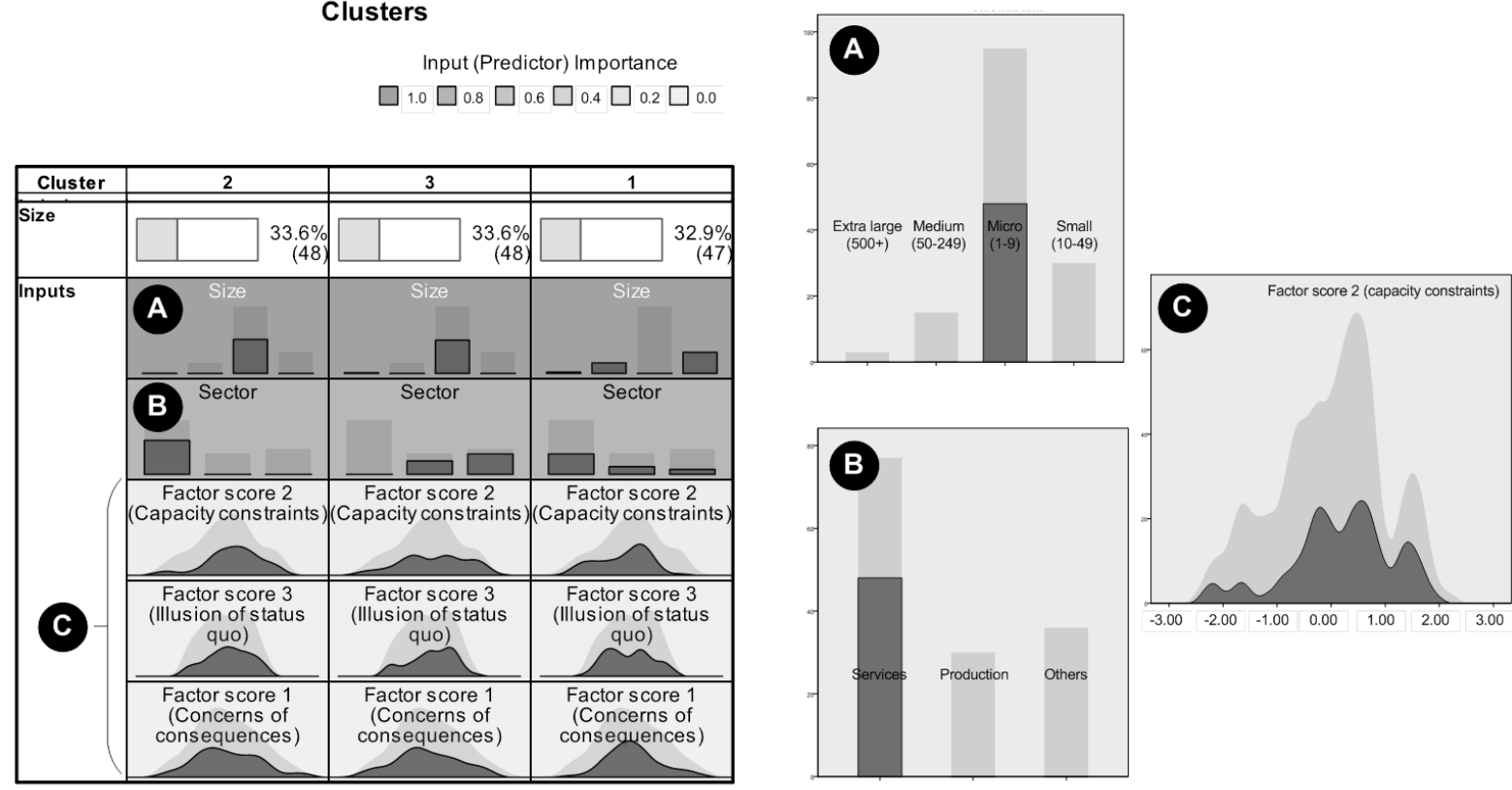

Source: Own calculation

Fig. 8: Results of two-step cluster analysis

Three types (groups) of organizations were identified; they were relatively equal when it comes to their representation. In Figure 8 a character of inputs/variables (i.e. characteristics) of organizations involved in a particular cluster may be seen. Since SPSS output options did not enable to name individual bar charts (lines A and B) and show scale for histograms (lines marked as C), an example of deployment of the first column (marked as cluster 2) can be found in the right part of the Figure. Based on these results, three types of organizations can be characterized briefly. The first group (marked as cluster 2) is represented by micro organizations especially from the area of services and which significantly perceive especially capacity constraints but are not afraid of negative impacts related to CS measurement (negative value of factor score prevails). The second group (marked as cluster 3 ) is made up of micro organizations from the area of production and other industries but the opinion is that their customers' needs do not change (positive value of factor score 3 prevails). The last group (marked as cluster 1) consists of small, medium and large organizations usually from the service sector which do not consider systematic CS measurement to be important since they are obviously not aware about its processes and benefits.

Generalization of these findings should be relativized and the size of sample set should be considered because the cluster analysis procedure can deal only with the cases which meet the requirement concerning a complete number of dimensions, in this case 5. Also for this reason a lot of cases with missing values were excluded by this procedure.

\section{Conclusion}

CS measurement is a process of validation of main, supportive and managing processes of an organization and may help its diagnostic aimed at its performance potential. So it is desirable to pay attention to searching barriers which make CS measurement more difficult or more complicated. The aim of the presented study was to discuss the main barriers and their representation in a selected sample. Considering possible methodological, realization and interpretation risks, several main findings of the study may be summarized: 
- More than a third of organizations do not pay CS measurement systematic attention and "Occasional measurement of CS" and "Lack of personnel" are considered to be the biggest barriers.

- In principle there are three main causes of why CS is not measured systematically: (1) Concerns of consequences, i.e. general prejudices and concerns concerning measurements results usually resulting from insufficient knowledge or experience; (2) Capacity constraints - internal restrictions making the measurement process more difficult, normally from the point of view of a lack of personnel or finance; (3) Illusion of status quo - an excessive belief that customers' needs stay stable whereby the belief may result from overestimation of own abilities or ignorance.

- Evaluation of CS measurement significance is on a higher level in a production sector in comparison to a service sector since the validation of product based on feedback is more problematic than in the case of service.

- It was proved that organizations which pay systematic attention to CS measurement perceive their results (success and market position) on a higher level than organizations which do not pay adequate attention to it.

- There are three types of organizations from the point of view of barriers evaluation: (1) micro organizations in which especially capacity constraints prevent to measure CS; (2) micro organizations which rely too much on the belief that customers' needs are stable and never change; (3) organizations with the number of employees higher than 10 which do not attach high importance to CS measurement.

The results of the presented research could support scientific discussion related to CS measurement and also to plans to ensure the process but also strengthen professional education of practitioners who work in the area of quality management.

\section{Literature}

[1] DROPPA, M.: Faktorová analýza - nástroj prosperity organizácie. Ružomberok: Verbum. 2010. 200 p. ISBN 9788080846145.

[2] DUDINSKÁ, E.; BUDAJ, P.; VITKO, Š.: Manažment v sociálnych službách. Prešov: Vydavatel'stvo Michala Vaška. 2009. 252 p. ISBN 9788071657569.

[3] GOLDER, P. N.; MITRA, D.; MOORMAN, C.: What is quality? An integrative framework of processes and states. Journal of Marketing. 2012. Vol. 76, No. 4, pp. 123.

[4] HRNČIAR, M.: Kvalita služieb - trvalá výzva. Žilina: Žilinská univerzita. 2014. 157 p. ISBN 9788055408101.

[5] CHEN, H.-G.; LIU, J. Y.-C.; SHEU, T. S.; YANG, M.-H.: The impact of financial services quality and fairness on customer satisfaction. Managing Service Quality. 2012. Vol. 22, No. 4, pp. 399-421.

[6] CHOWDHURY, M. M. H.; QUADDUS, M. A.: A multi-phased QFD based optimization approach to sustainable service design. International Journal of Production Economics. Forthcoming. Published online September 29th, 2014.

[7] LEDWITH, A.; O'DWYER, M.: Market orientation, NPD performance, and organizational performance in small firms. Journal of Product Innovation Management. 2009. Vol. 26, No. 6, pp. 652-661. 
[8] McCOLL-KENNEDY, J.; SCHNEIDER, U.: Measuring customer satisfaction: Why, what and how. Total Quality Management. 2000. Vol. 11, No. 7, pp. S883-S896.

[9] McKINNEY, V.; YOON, K.; ZAHEDI, F.: The measurement of Web-customer satisfaction: An expectation and disconfirmation approach. Information Systems Research. 2002. Vol. 13, No. 3, pp. 296-315.

[10] PARASURAMAN, A.; ZEITHAML, V. A.; BERRY, L. L.: SERVQUAL: a multi-item scale for measuring consumer perceptions of the service quality. Journal of Retailing. 1988. Vol. 64, No. 1, pp. 12-40.

[11] PIERCY, N.: Market-led strategic change. Oxford: Butterworth-Heinemann. 2002. 754 p. ISBN $075065225 \mathrm{X}$.

[12] SHENG, T.; LIU, C.: An empirical study on the effect of e-service quality on online customer satisfaction and loyalty. Nankai Business Review International. 2010. Vol. 1, No. 3, pp. 273-283.

[13] SOUITARIS, V.: Strategic Influences of Technological Innovation in Greece. British Journal of Management. 2001. Vol. 12, No. 2, pp. 131-147.

[14] SVETLIČIČC, M.; JAKLIČ, A.; BURGER, A.: Internationalization of small and medium-size enterprises from selected Central European Economies. Eastern European Economics. 2007. Vol. 45, No. 4, pp. 36-65.

[15] TALKE, K.; HULTINK, E. J.: Managing diffusion barriers when launching new products. Journal of Product Innovation Management. 2010. Vol. 27, No. 4, pp. 537553.

[16] TSAI, M.-T.; TSAI, C.-L.; CHANG, H.-C.: The effect of customer value, customer satisfaction, and switching costs on customer loyalty: An empirical study of hypermarkets in Taiwan. Social Behavior and Personality. 2010. Vol. 38, No. 6, pp. 729-740.

Mgr. Peter Madzík, Ph.D.; Mgr. Ing. Pavol Križo, Ph.D. 


\section{INTENZITA A VNÍMANIE BARIÉR MERANIA SPOKOJNOSTI ZÁKAZNÍKOV}

I ked’ informácie z merania spokojnosti zákazníka (CS) patria medzi cenné spúštače zlepšovacích aktivít, $\mathrm{v}$ praxi organizácie narážajú na rôzne bariéry, ktoré zabraňujú aby bolo meranie systematické. Predkladaná štúdia si kladie za ciel' preskúmat' intenzitu a samotné vnímanie bariér brániacich meraniu CS. K tomuto cielu je využité štatistické spracovanie výsledkov prieskumu realizovaného $\mathrm{v}$ rámci Slovenskej republiky. Spracovaných bolo celkovo 435 platných dotazníkov, prostredníctvom ktorých boli identifikované a kvantifikované vzt’ahy medzi jednotlivými bariérami merania CS. Výsledky ukázali, že za najväčšie bariéry možno považovat' nepravidelnost' merania spokojnosti zákazníka a nedostatok personálu.

\section{INTENSITÄT UND WAHRNEHMUNG DER MESSUNG DER ZUFRIEDENHEIT DER KUNDEN}

Wenngleich die aus Messungen der Kundenzufriedenheit (CS) gewonnenen Informationen zu den wertvollen Auslösern von Verbesserungsaktivitäten zählen, stoßen sie in der Praxis auf verschiedene Barrieren, welche eine systematische Messung verhindern. Die vorgelegten Studien haben sich zum Ziel gesetzt, die Intensität und die eigentliche Wahrnehmung der Barrieren zu erforschen, welche eine Messung der Kundenzufriedenheit erschweren. $\mathrm{Zu}$ diesem Zweck wird eine statistische Verarbeitung der Ergebnisse einer Forschung genutzt, welche im Rahmen der Slowakischen Republik durchgeführt worden ist. Insgesamt wurden 435 gültige Fragebögen bearbeitet, mittels welcher die Beziehungen zwischen den einzelnen Barrieren der CS-Messung identifiziert und quantifiziert wurden. Die Ergebnisse zeigten, dass als die größten Messungshemmer eine dünne CS-Messfrequenz sowie eine unzureichende Personaldecke zu betrachten sind.

\section{NATĘŻENIE I POSTRZEGANIE BARIER BADANIA SATYSFAKCJI KLIENTA}

Chociaż informacje wynikające $\mathrm{z}$ badania satysfakcji klienta należą do cennych bodźców działań udoskonalających, $w$ praktyce organizacje napotykają się na różne bariery uniemożliwiające systematyczne przeprowadzanie ww. badania. Przedstawiane w artykule badania mają na celu sprawdzenie natężenia i postrzegania barier uniemożliwiających przeprowadzanie badań satysfakcji klienta. W tym celu wykorzystano statystyczne opracowanie wyników badań przeprowadzonych w ramach Republiki Słowackiej. Opracowano łącznie 435 ważnych ankiet, za pośrednictwem których zidentyfikowano oraz skwantyfikowano zależności pomiędzy poszczególnymi barierami dla badań satysfakcji klienta. Wyniki wskazały na fakt, że jako największe bariery można potraktować badania okazjonalne oraz niedobór personelu. 